\title{
Kinetic study of carbazole degradation by free and immobilized Thalassospira profundimaris
}

\author{
Putera Nik Aiman Mustaqim Othman ${ }^{1}$, Othman Inayatullah ${ }^{2 *}$ \\ ${ }^{1}$ Fuel Cell Institute, University Kebangsaan Malaysia, Malaysia \\ ${ }^{2}$ School of Engineering and Technology, University College of Technology Sarawak, Malaysia
}

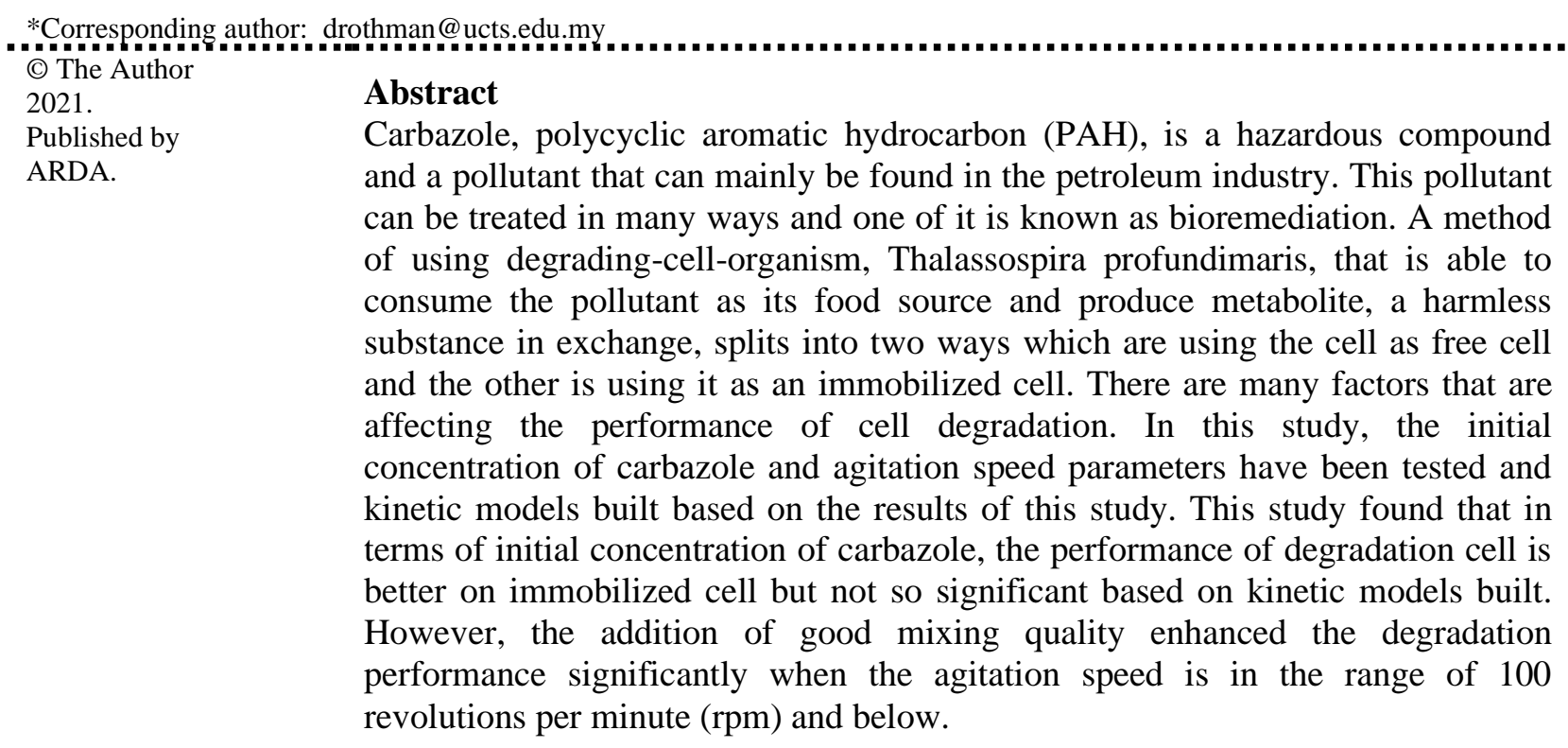

Keywords: Thalassospira profundimaris; Kinetic; Carbazole; Biodegradation; Immobilization; Concentration; Agitation speed

\section{Introduction}

Hydrocarbon water pollution is a serious problem that may occur due to petroleum, pesticides or other toxic organic matter. The biggest concern is the hydrocarbon-water pollution caused by petroleum industry because the hydrocarbon contaminant produced by the petroleum industry is toxic to all life forms. Disposal from the petroleum industry itself or spillage during the transfer made can cause a huge impact on many life forms and not just to aquatic life forms. The petroleum is actually a complex mixture that contains saturated alkanes, branched alkanes, alkenes, aromatics and more [1]

Carbazole, polycyclic aromatic hydrocarbon (PAH) heterocycle is one of the hydrocarbon pollutions compounds that exists. Heterocycles are generally water-soluble compounds that tend to have lower $\log$ octanol-water partition coefficients than unsubstituted PAHs which lead to less tendency of soil particles sorb [2]. It is also found that the toxicities of heterocycles carbazole are insignificantly different than the unsubstituted hydrocarbon counterparts and the CAR, as it has been found that, does not undergo mutagenic like other PAHs [2]. This pollutant can be treated by using one of the Thalassospira genus species known as bioremediation or biodegradation.

One of the Thalassospira genus species is known as Thalassospira profundimaris (T. profundimaris) and the species is non-motile, non-flagellated, and non-spore-forming cells. The cells are mesophilic, able to grow well in moderate temperature which is between $10^{\circ} \mathrm{C}$ and $37^{\circ} \mathrm{C}$ with $22{ }^{\circ} \mathrm{C}$ being the optimum temperature [3]. The bacteria also required sodium chloride $(\mathrm{NaCl})$ in between $2 \%$ to $8 \%$ of concentration to grow, with

This work is licensed under a Creative Commons Attribution License (https://creativecommons.org/licenses/by/4.0/ ) that allows others to share and adapt the material for any purpose (even commercially), in any medium with an acknowledgement of the work's authorship and initial publication in this journal. 
optimum concentration to be $3 \%$ to $4 \%$, and are sensitive to many types of antibiotic [3]. These cells can be isolated from deep-sea sediment.

There are two ways to use the T. profundimaris cells in degradation process; using it as free cells or by modifying it into immobilized cells. Based on the research that has been done by other researchers, the usage of immobilized microorganism is more advantageous to improve the stability of the biocatalyst and to simplify its recovery and reusability compare to the usage of free cells [4]. However, the usage of immobilized cells does come with disadvantage which is the mass transfer limitation, also known as rate of diffusion. By using the immobilized cells, the composite of the immobilized component (enclosure) that usually look like gel, need to be at optimum in order for carbazole to penetrate and react with $\mathrm{T}$. profundimaris cells without the gel breaking into pieces. If it does break, one of the advantages is the simplicity of recovery and reusability.

The study of the hydrocarbon-water pollution remediation has been done by using the T. profundimaris on carbazole degradation samples collected in a batch bioreactor in the laboratory. The study involves the discussion on the kinetic reaction that depends on substrate concentration as the manipulated variable in order to identify the best condition for the cells to reach maximum degradation performance between the optimum immobilized cells and free cells. Also, the study has the discussion on the kinetic reaction that involves other manipulated variable, agitation speed.

\section{Methodology}

\subsection{Cell cultivation}

Since Thalassospira profundimaris is a marine type of cell, an artificial sea water media was prepared by using the general compositions of the real sea water, known as ONR 7a media. Cell cultivation from extraction cell sample was done in a clean petri dish with two layers of agar. The bottom layer only contained ONR 7a and agar while the upper layer contained ONR $7 \mathrm{a}$, agar, $0.1 \%$ of carbazole and the cells from sea-extraction sample froze in glycerol. This arrangement helps in observing the clear zone, which indicates where the cells location is. The clear zone can be seen from bottom layer since the carbazole only exists on upper layer. The purpose of cultivation on plate was to ensure that the cells grown were indeed Thalassospira profundimaris for bigger scale cultivation in flask. It was found that the cells took minimum one week to be visible on the plate. Cultivation in flask was done by filling up the conical flask with 2:1 ratio of ONR 7a to marine broth. Marine broth was used to supply the nutrition needed by cells to grow faster. The ratio used was perfect for two days' cultivation in $500 \mathrm{ml}$ conical flask, $200 \mathrm{ml}$ ONR 7a and $100 \mathrm{ml}$ marine broth. Cells from petri dish were transferred into sterilized cultivation flask by using inoculating loop and the flask was left at shaker equipment.

After two days, the solution in flask was centrifuged in two rounds. The first round was in big scale centrifuge and second round was in small scale centrifuge. The first centrifuge was basically method to separate the cells from the ONR 7a with marine broth solution, while the second centrifuge required phosphate buffer saline to maintain the $\mathrm{pH}$ of cells and to wash the cells from remaining unwanted solutions. The fresh grown cells can be stored in refrigerator for maximum of seven days.

\subsection{Cells immobilization technique}

T. profundimaris cells in gellan gum preparation were done by a two-phase dispersion technique known as emulsification and will end with internal gelation process that solidifies the bacteria in the gel [5]. During the emulsification process, the dispersion of gellan gum was dissolved in $55 \mathrm{ml}$ of the deionized water with $0.75 \%$ $(\mathrm{w} / \mathrm{v})$ of gellan gum heated until the temperature reaches $75^{\circ} \mathrm{C}$ to $80^{\circ} \mathrm{C}$. After that, the process continued with the addition of $0.06 \%(\mathrm{w} / \mathrm{v})$ of calcium chloride $(\mathrm{CaCl} 2)$ which was cooled to $45^{\circ} \mathrm{C}$. The $\mathrm{pH}$ of the solution was adjusted until it reaches $\mathrm{pH} 7$ with sodium hydroxide $(\mathrm{NaOH})$ before addition of bacteria. The cell culture of the bacteria in form of pellets was collected from cells cultivation made and dispersed in the pre-gel solution made. It was then emulsified in cooking oil with 1-1 stirred baffled cylindrical vessel with a constant temperature of $45^{\circ} \mathrm{C}$ with gentle stir to avoid the breakage of the microbeads. The temperature was cooled down lower to $25^{\circ} \mathrm{C}$ with continuous stirring and then the beads were filtered from the oil dispersion by partitioning into $0.1 \%(\mathrm{w} / \mathrm{v}) \mathrm{CaCl} 2$ solution for further solidifying process. The beads were then rinsed into Tween 80 to remove all the oil from the bead surface before it was stored in the refrigerator with distilled water for one day. 


\subsection{Degradation with various initial concentration of carbazole}

Multiple flasks were set-up where each pair of flasks contained same concentration of carbazole in ONR 7a solution. Total of three pairs of flasks with three different initial concentrations of carbazole which were 1000 ppm, $1500 \mathrm{ppm}$ and $2000 \mathrm{ppm}$. A pair of flasks was tested with free cells on one flask and immobilized cells for another flask for all three pairs. The experiment ran for 42 hours at ambient temperature, $\mathrm{pH} 7$ and samples were taken at every 6 hours interval. This experiment was repeated for three times for accurate analysis.

\subsection{Degradation with various agitation speed}

This parameter was tested in bioreactor of $2000 \mathrm{ml}$ volume contained of $1000 \mathrm{ml}$ of ONR 7a with constant concentration of carbazole throughout the whole experiments, $1000 \mathrm{ppm}$. The experiment was tested with three values of agitation speed, $100 \mathrm{rpm}, 150 \mathrm{rpm}$ and $200 \mathrm{rpm}$. The reactor ran for average of 40 hours and above and the experiment for each agitation speed was repeated twice for high accuracy in analysis. The aeration was set at maximum to give excess oxygen for the cells to achieved maximum capability on degradation at constant $\mathrm{pH}$ 7. Samples were taken from time to time but not constant due to equipment accesses limitation.

\subsection{Analytical method}

The internal standard for carbazole was run with various concentrations of carbazole $(500,1000,1500,2000$ and $2500 \mathrm{mg} / \mathrm{L}$ ). This step was to identify the runtime and retention time of the carbazole before injecting the sample analyte. The standard chromatogram that gave a standard peak area for carbazole from the internal standard process was used to identify the rest of the concentration of the sample [6]. The $1 \mathrm{ml}$ of samples extracted were combined with $1 \mathrm{ml}$ of ethyl acetate and mixed by using vortex mixer equipment. The ethyl acetate separates samples into two layers that differentiate polar and non-polar to remove water from carbazole. The carbazole and ethyl acetate solvent that are both non-polar and have light density were on the upper layer, extracted into vial tube for GC/FID analysis process. Then, extracted carbazole with ethyl acetate $(1 \mu \mathrm{L})$ was injected with nitrogen as the carrier gas and the temperature of the injector and detector maintained at $220^{\circ} \mathrm{C}$ and $250^{\circ} \mathrm{C}$ respectively [6].

\subsection{Kinetic study method}

Kinetic model used as in this study is Monod kinetic equation that shows relationship of concentration of carbazole and time as shown in (1).

$$
\mu=\frac{\mu_{\max } S}{k_{S}+S}
$$

where the specific growth rate of carbazole degraded, $\mu$ can be determined based on the $\mu_{\max }$, maximum of specific growth rate of the carbazole which can convert into a maximum of specific degradation rate since the growth of cell and degradation are proportional to each other. $S$ is the substrate concentration and $k_{s}$ is the half-velocity constant value that needs to be found out through experimental results.

The modified equations based on the type of reaction applicable for this study, whether zero order reaction or first order reaction, were determined based on the data collected and analyzed from experiments. Zero order modified Monod kinetic model is shown in (2) while first order modified Monod kinetic model is shown in (3).

$$
\begin{aligned}
& c=b+k_{o} t \\
& \text { In } c=a+k_{1} t
\end{aligned}
$$

where, $k_{o}$ and $k_{l}$ is the maximum specific biodegradation rate constant that refer to the slope of the trend line, while $b$ and $a$ are constant, $t$ is time and $c$ is initial concentration of carbazole. 


\section{Results and discussion}

\subsection{Effect of initial substrate concentration on carbazole degradation}

The kinetic model equation applied in this study is from Monod kinetic equation model and is based on the result of samples collected for 48 hours. The T. profundimaris cells show zero order reaction on all initial carbazole concentration tested up to $2000 \mathrm{mg} / \mathrm{L}$ or ppm. Zero-order of Monod kinetic model (2) is simply a linear trend line where the biodegradation rate is constant and can be found based on the gradient of that trend line as shown in Fig. 1. The zero-order reaction model has been found as the best model that fits lab and field data where it is convenient to be used. Since the model can result in negative concentrations, it should not be used for prediction of transformation rates outside the range of the existing data [7].

Based on Fig. 1 and Table 1, both free and immobilized cells were able to achieve high degradation rate when the initial concentration of carbazole increased which are $12.203 \mathrm{mg} / \mathrm{L} \cdot \mathrm{H}$ and $15.294 \mathrm{mg} / \mathrm{L} \cdot \mathrm{H}$ respectively. Due to a small range of tested parameter values, it cannot be concluded that at $2000 \mathrm{mg} / \mathrm{L}$ for both cells are the optimum value because it can be seen that both free and immobilized cells will be able to handle much higher concentration that tested value until the order of reaction changes. It can be concluded that the immobilized cell, which has better biodegradation rate constants in all value of initial concentration, gives a better performance in degrading carbazole into lower concentration in 48 hours, while free cell performance is subpar when comparing to immobilized cell. The reason behind this phenomenon is that a cell which is also a living organism can be affected by environment conditions, such as the level of toxicity. During the degradation process, both free and immobilized cells will undergo growing and drying process. Free cell that does not have protection against high toxicity level has lower rate of growing and high rate of dying that results in lower removal efficiency of carbazole while comparing to immobilized cell that has gel matrix protection which results in higher efficiency of carbazole removal [8].
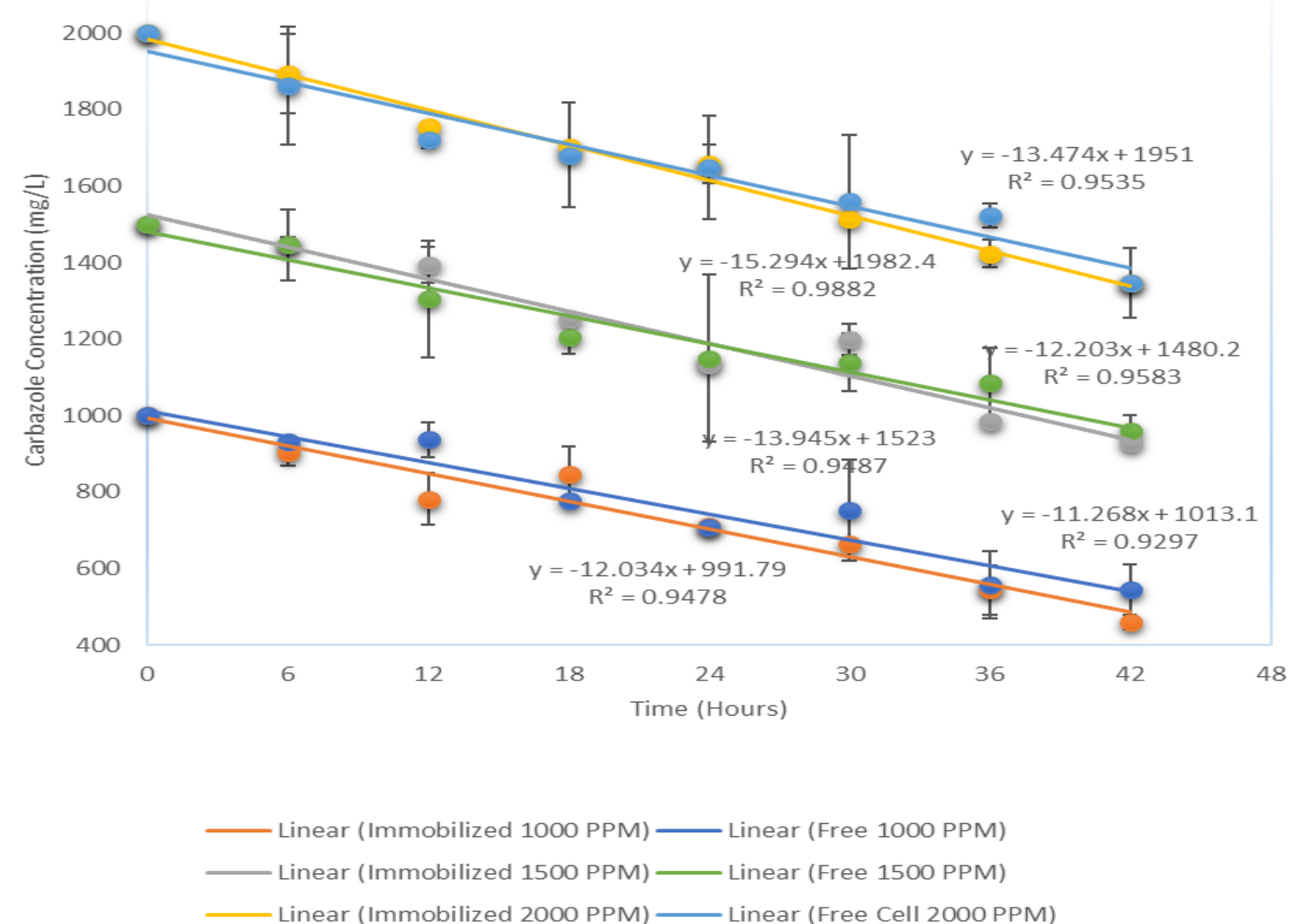

Figure 1. Degradation rate Monod zero order trend line at 1000, 1500 and 2000 ppm in flask scale 
Table 1. Kinetic study of immobilized and free cells on various initial concentration

\begin{tabular}{ccccc}
\hline Type & $\begin{array}{c}\text { Initial Carbazole } \\
\text { Concentration }(\mathrm{mg} / \mathrm{L})\end{array}$ & Kinetic Equation & $\begin{array}{c}\text { Biodegradation Rate } \\
\text { Constant }(\mathrm{mg} / \mathrm{L} \cdot \mathrm{H})\end{array}$ & $\begin{array}{c}\text { Correlation } \\
\text { coefficient }\left(\mathrm{r}^{2}\right)\end{array}$ \\
\hline \multirow{3}{*}{ Immobilized } & 1000 & $\mathrm{C}=-12.034 \mathrm{t}+991.79$ & 12.034 & 0.95 \\
\multirow{3}{*}{ Free } & 1500 & $\mathrm{C}=-13.945 \mathrm{t}+1523.00$ & 13.945 & 0.95 \\
& 2000 & $\mathrm{C}=-15.294 \mathrm{t}+1982.4$ & 15.294 & 0.99 \\
\hline & 1000 & $\mathrm{C}=-11.268 \mathrm{t}+1013.10$ & 11.268 & 0.93 \\
& 1500 & $\mathrm{C}=-12.203 \mathrm{t}+1480.2$ & 12.203 & 0.96 \\
\hline
\end{tabular}

Based on Fig. 2, it can be seen that the gap percentage of biodegradation rate constant between free and immobilized cells smaller at $2000 \mathrm{ppm}$ compare to $1500 \mathrm{ppm}$. It can be predicted that if the initial concentration of carbazole increases more, the performance of immobilized and free cells will have no significant different which can be seen at Table 2. The final decrement percentage between free and immobilized cells at $2000 \mathrm{ppm}$ does not have significant difference when at $32.73 \%$ and $32.70 \%$ of $2000 \mathrm{ppm}$ degraded after 42 hours. This phenomenon is due to the long lag time required by the immobilized cells to accommodate high concentration of carbazole and start to degrade it [9].

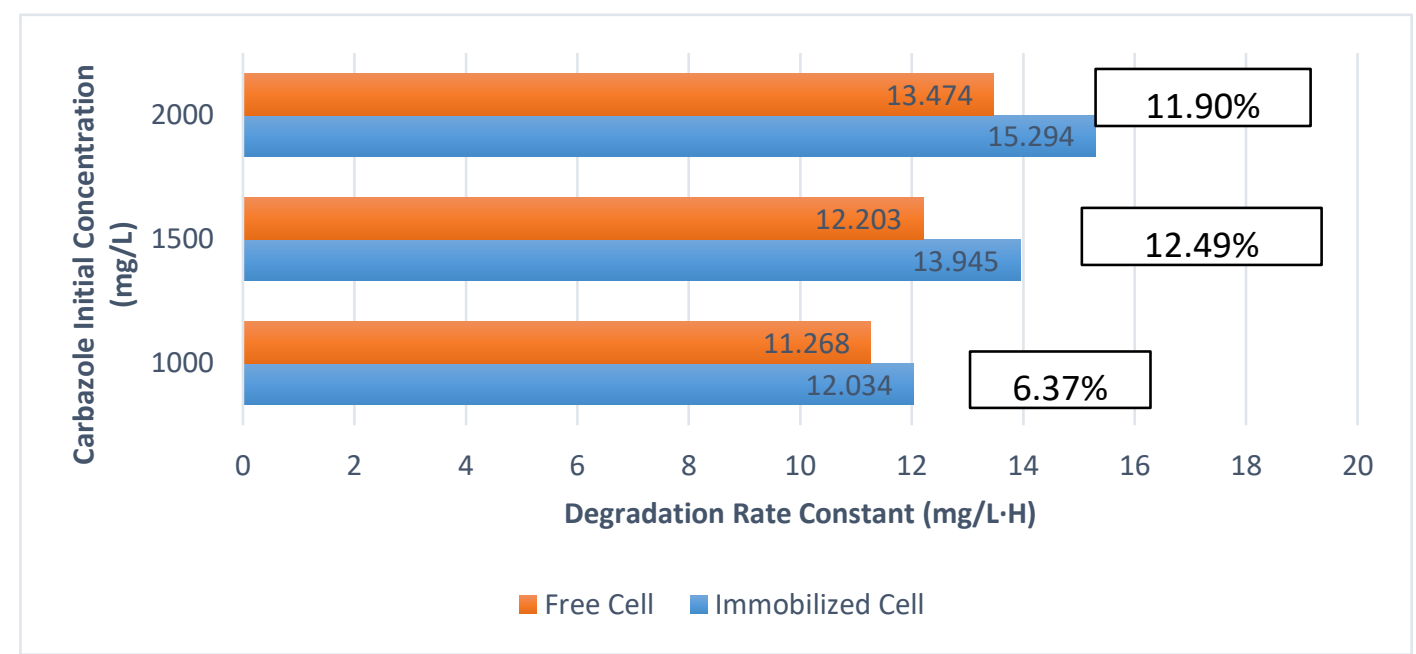

Figure 2. Degradation rate constant at 1000, 1500 and 2000 ppm in flask scale

Table 2. Decrement of carbazole concentration from initial value (\%) with difference initial concentration of carbazole

\begin{tabular}{ccccccc}
\hline \multicolumn{7}{c}{ Decrement $(\%)$} \\
\hline Time & \multicolumn{2}{c}{1000 PPM } & \multicolumn{2}{c}{1500 PPM } & \multicolumn{2}{c}{ 2000 PPM } \\
Hour & Immobilized & Free & Immobilized & Free & Immobilized & Free \\
\hline 0 & 0.00 & 0.00 & 0.00 & 0.00 & 0.00 & 0.00 \\
6 & 9.72 & 6.73 & 3.43 & 3.56 & 5.32 & 6.83 \\
12 & 21.80 & - & 7.08 & 12.99 & 12.20 & 13.96 \\
18 & - & 22.13 & 16.41 & 19.55 & 14.92 & 15.92 \\
24 & 28.77 & 29.24 & 24.46 & 23.35 & 17.11 & 17.53 \\
30 & 33.41 & - & - & 24.08 & 24.39 & 22.03 \\
36 & 45.66 & 44.16 & 34.35 & 27.61 & 28.82 & 23.80 \\
42 & 54.08 & 45.52 & 38.15 & 36.10 & 32.73 & 32.70 \\
\hline
\end{tabular}




\subsection{The performance of biodegradation in bioreactor scale with various speed of agitation by immobilized cells}

Based on Fig. 3, the result shows that the agitation speed parameter has a significant impact on the biodegradation performance where at $100 \mathrm{rpm}$ of agitation speed, the $1000 \mathrm{ppm}$ of carbazole degraded with biodegradation rate constant of $19.23 \mathrm{mg} / \mathrm{L} \cdot \mathrm{H}$. But, the higher the agitation speed increases, the lower the biodegradation rate constant. The mixing quality at high agitation speed, more than $100 \mathrm{rpm}$ proved to give negative effect on the diffusion rate of nutrients and carbazole into the matrix of gellan gum gel. The trend will be similar if tested with the free cell where the cells would not have high efficiency in nutrient and carbazole absorption [10].

Based on Table 3, it shows the detail of the zero order Monod kinetic model developed for those three values of agitation speed. It can be concluded that the optimum agitation speed for carbazole degradation is $100 \mathrm{rpm}$ and below. Based on the kinetic developed in Fig. 3 and Table 3, $1000 \mathrm{ppm}$ of carbazole is able to be fully degraded in less than 48 hours while higher than $100 \mathrm{rpm}$ agitation is unable to degrade $1000 \mathrm{ppm}$ of carbazole completely within 48 hours. The highest decrement, $90.16 \%$ of initial carbazole concentration, degraded after 44 hours at $100 \mathrm{rpm}$ of agitation speed. During the experiment observations were made on the condition of the immobilized cells tested with various speeds of agitation before and after the duration of the experiment. It can be seen clearly that the immobilized cells by using gellan gum as gel material, cannot withstand agitation speed at $200 \mathrm{rpm}$ and above where after the duration of the experiment, the beads had a significant amount of breakage that causes the degradation performance to be a hybrid rather than immobilized cells performance. Biodegradation rate constant at $200 \mathrm{rpm}$ is so low due to cells escaped from the broken bead that cause the cells having no protection against the toxicity of the carbazole.

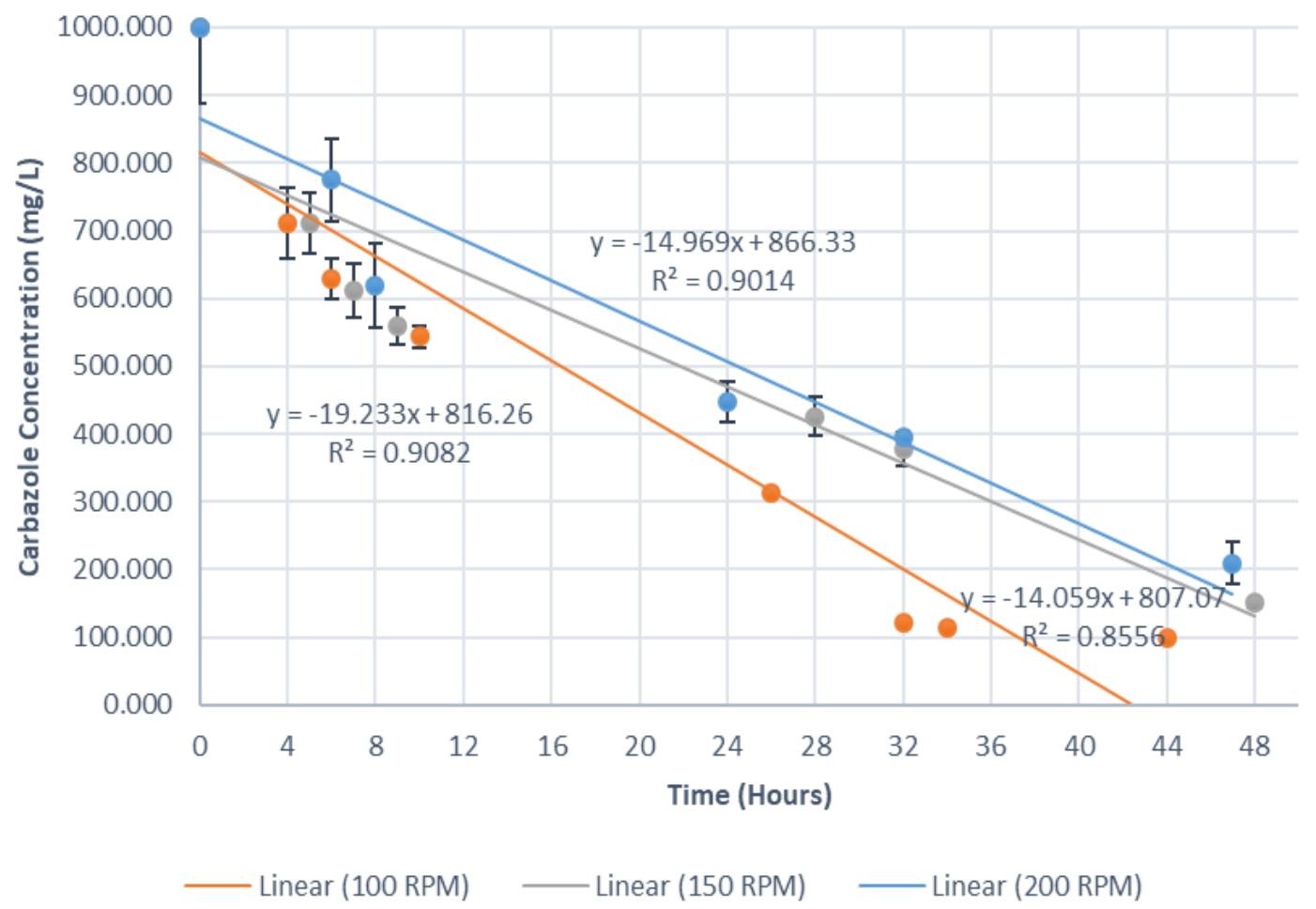

Figure 3. Biodegradation rate trend at 100, 150 and $200 \mathrm{rpm}$ agitation speed in bioreactor scale

Table 3. Kinetic study of immobilized cell with various agitation speed

\begin{tabular}{cccc}
\hline Agitation Speed (rpm) & Kinetic Equation & $\begin{array}{c}\text { Biodegradation Rate } \\
\text { Constant }(\mathrm{mg} / \mathrm{L} \cdot \mathrm{H})\end{array}$ & $\begin{array}{c}\text { The correlation } \\
\text { coefficient }\left(\mathrm{r}^{2}\right)\end{array}$ \\
\hline 100 & $\mathrm{C}=-19.23 \mathrm{t}+816.26$ & 19.230 & 0.91 \\
150 & $\mathrm{C}=-14.059 \mathrm{t}+807.07$ & 14.059 & 0.86 \\
200 & $\mathrm{C}=-14.969 \mathrm{t}+866.33$ & 14.969 & 0.90 \\
\hline
\end{tabular}




\subsection{The comparison of biodegradation performance in shake flask and bioreactor scale}

Fig. 4 summarized all degradation rate data collected where the initial concentration of carbazole is $1000 \mathrm{ppm}$ or $\mathrm{mg} / \mathrm{L}$, under two conditions: an immobilized cell in shake flask scale and immobilized cell in bioreactor scale with 100, 150 and $200 \mathrm{rpm}$ speed of agitation. This comparison is simply to show how much is scaling up into proper treatment equipment able to enhance the degradation rate from flask scale. Table 4 shows the percentage of performance enhances at a specific time after the experiment start-up. Due to the limitation of time and authority, not all data were available at specific hour, and require some interpolation to be done in order to do the comparison. Linear interpolation can be made due to linear trend from Monod kinetic model which was applied to all tested experiment.

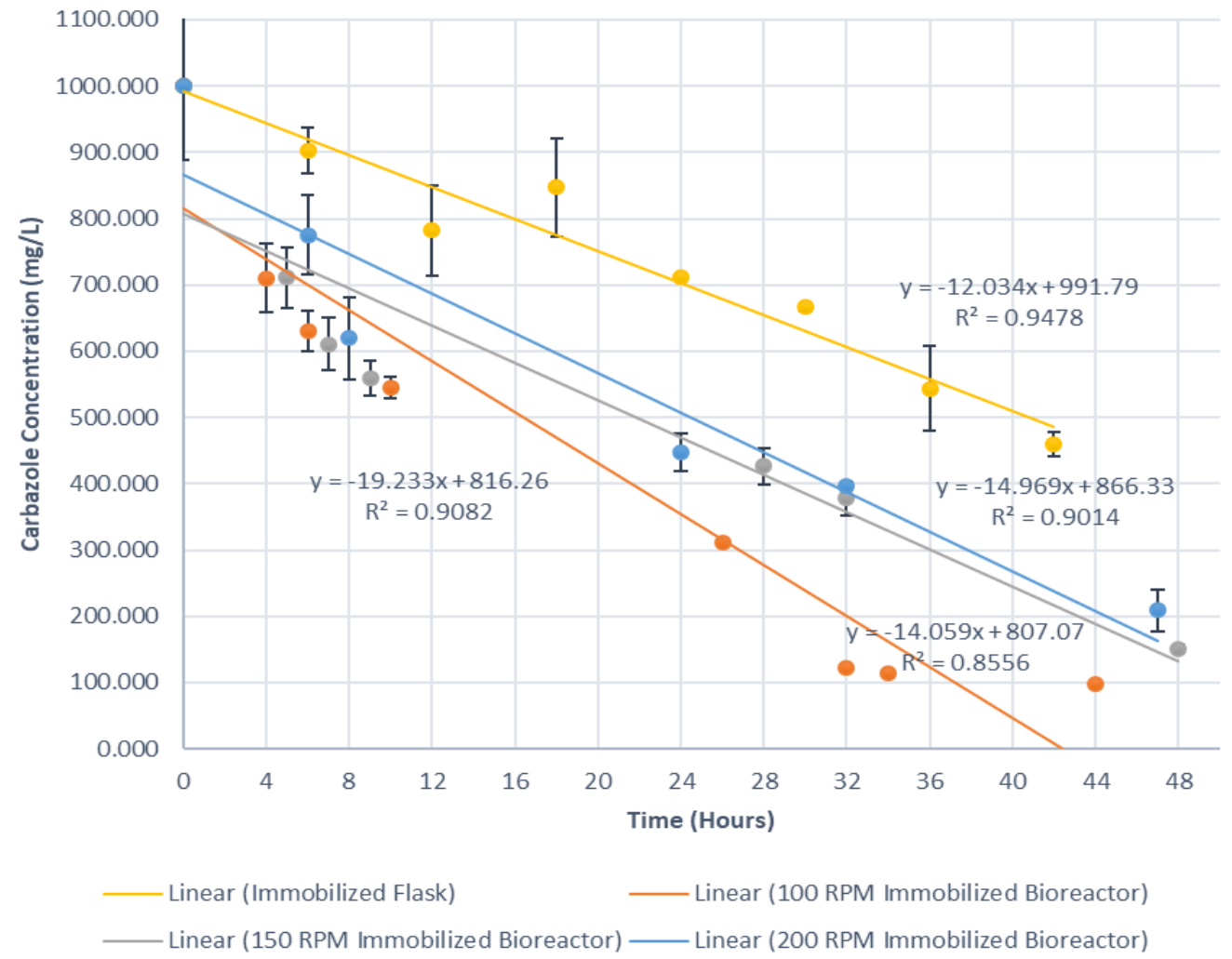

Figure 4. Performance comparison between bioreactor scale and flask

Table 4. Performance enhanced comparison from shake flask to bioreactor scale with various agitation speed

\begin{tabular}{cccc}
\hline \multicolumn{4}{c}{ Performance Enhance (\%) } \\
\hline $\begin{array}{c}\text { Time } \\
\text { (Hour) }\end{array}$ & $\begin{array}{c}\text { Bioreactor at 100 rpm } \\
\text { against Flask }\end{array}$ & $\begin{array}{r}\text { Bioreactor at 150 rpm } \\
\text { against Flask }\end{array}$ & $\begin{array}{c}\text { Bioreactor at 200 rpm } \\
\text { against Flask }\end{array}$ \\
\hline 6 & 73.75 & 71.33 & 56.84 \\
12 & 55.03 & 52.78 & 48.56 \\
24 & 56.34 & 47.30 & 47.94 \\
30 & 57.26 & 44.15 & 43.48 \\
36 & 44.46 & 31.21 & 28.38 \\
42 & 34.59 & 25.48 & 21.39 \\
\hline
\end{tabular}

Based on Table 4, significant enhancement can be seen at the first 6 hours after the experiment started where it improves as high as $73.75 \%$ compare to early 6 hours of flask scale and as the time passed by until 42 hours, the enhancement of performance percentage decrease slowly due to low concentration of carbazole as time passed. Optimum agitation speed with constant volume and excess of oxygen concentration affect positively the biodegradation performance in term of time consumption for the process to complete. 


\section{Conclusion}

The results of this study are as follows:

a. The cells are able to maintain zero order reaction for initial concentration of carbazole up until 2000 which means that the degradation with that high concentration does not affect other types of parameter.

b. It was also found that the agitation speed is able to enhance the biodegradation performance and at low agitation speed, $100 \mathrm{rpm}$. The better mixing quality it provides increases the efficiency of diffusion through gellan gum matrix that is protecting the cells. The slow mixing allowed sufficient time for carbazole to diffuse into and metabolite to diffuse out from the gel matrix. It is also found that the gellan gum as immobilization material is not able to hold up its own gel matrix when the speed of agitation goes $200 \mathrm{rpm}$ and over.

c. In a comparison to kinetic model, the immobilized cell enhances the degradation performance compared to free cells, but under the various initial concentration of substrate it seems that the parameter tested does not give the significant difference between the usage of free cells and immobilized cell when handling carbazole concentration from $1000 \mathrm{ppm}$ and above. However, kinetic model developed from the various speed of agitation testing concluded that the agitation speed gives significant influence to the biodegradation performance.

d. Further studies on other immobilization material shows that various volumes of reactor and temperature could be carried out to identify more parameters that could give significant effect toward this bio-remediation technique in eliminating hazardous hydrocarbon.

e. The usage of gellan gum as an immobilization support material that requires emulsification is a disadvantage in term of procedure cost. This may require other technique or changing the material so that the procedure does not involve any heating process, because the cell $\mathrm{T}$. profundimaris is not able to withstand temperature higher than 45 degrees Celsius. The higher risk for the cell to be dead needs higher cost investment in preventing it, which is a downside to the usage of gellan gum.

\section{References}

[1] S. Abha, and C. S. Singh, "Hydrocarbon Pollution: Effects on Living Organisms, Remediation of Contaminated Environments, and Effects of Heavy Metals Co-Contamination on Bioremediation," Introduction to Enhanced Oil Recovery (EOR) Processes and Bioremediation of Oil-Contaminated Sites, pp. 185-206, 2012.

[2] D. M. Wassenberg, A. L. Nerlinger, L. P. Battle, and R. T. Di Giulio, "Effects of the polycyclic aromatic hydrocarbon heterocycles, carbazole and dibenzothiophene, on in vivo and in vitro CYP1A activity and polycyclic aromatic hydrocarbon-derived embryonic deformities," Environmental Toxicology and Chemistry, vol. 24(10), pp. 2526-2532, 2005.

[3] C. Liu, Y. Wu, L. Li, M. Yingfei, and Z. Shao, "Thalassospira xiamenensis sp. nov. and Thalassospira profundimaris sp. nov.," International Journal of Systematic and Evolutionary Microbiology, vol. 57(2), pp. 316-320, 2007.

[4] X. Wang, Z. Gai, B. Yu, J. Feng, C. Xu, Y. Yuan, Z. Lin, and P. Xu, "Degradation of carbazole by microbial cells immobilized in magnetic gellan gum gel beads," Applied and Environmental Microbiology, vol. 73(20), pp. 6421-6428, 2007.

[5] P. Moslemy, R. J. Neufeld, D. Millette, and S. R. Guiot, "Transport of gellan gum microbeads through sand: An experimental evaluation for encapsulated cell bioaugmentation," Journal of Environmental Management, vol. 69(3), pp. 249-259, 2003.

[6] L. B. Salam, M. O. Ilori, and O. O. Amund, "Carbazole degradation in the soil microcosm by tropical bacterial strains," Brazilian Journal of Microbiology, vol. 46(4), pp. 1037-1044, 2015.

[7] B. A. Bekins, E. Warren, and E. M. Godsy, "A comparison of zero-order, first-order, and monod biotransformation models," Ground Water, vol. 36(2), pp. 261-268, 1998.

[8] L. Jiang, Q. Ruan, R. Li, and T. Li, "Biodegradation of phenol by using free and immobilized cells of Acinetobacter sp. BS8Y," Journal of Basic Microbiology, vol. 53(3), pp. 224-230, 2013.

[9] W. Jianlong, Q. Xiangchun, H. Liping, Q. Yi, and W. Hegemann, "Microbial degradation of quinoline by immobilized cells of Burkholderia pickettii," Water Research, vol. 36(9), pp. 2288-2296, 2002. 
[10] S. R, Khan, J. I. Kumar Nirmal, R. N. Kumar, and J. G. Patel, "Biodegradation of kerosene: Study of growth optimization and metabolic fate of P. janthinellum SDX7," Brazilian Journal of Microbiology, vol. 46(2), pp. 397-406, 2015. 